\title{
THE SHUILIAN CAVE IN THE UPPER REGION OF THE CHANG RIVER (KARST OF NW YUNNAN, CHINA)
}

\author{
JAMA SHUILIAN V ZGORNJEM POREČJU REKE CHANG \\ (KRAS SEVEROZAHODNEGA YUNNANA, KITAJSKA)
}

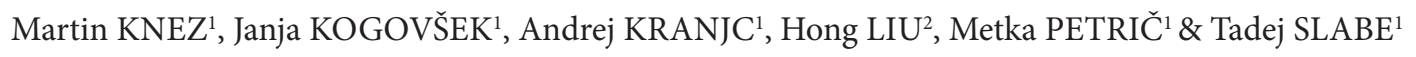

\begin{abstract}
UDC 911.2:551.435.84(510)

Martin Knez, Janja Kogovšek, Andrej Kranjc, Hong Liu, Metka Petrič \& Tadej Slabe: The Shuilian cave in the upper region of the Chang river (Karst of NW Yunnan, China)

In upper reaches of the Chang (Yangtze) river, in Deqen prefecture, in northwestern part of the Yunnan province, karst is developed in Devonian carbonate rocks. The Shuilian cave, more than a kilometre long, formed along the contact of fine bedded metamorphosed calcitized sandy siltstones and calcitized siltstones. The cave has two entrances, the upper one being dry and the lower entrance with a steady water flow. It is situated in the steep slope about $70 \mathrm{~m}$ above the river level (1,965 $\mathrm{m}$ a.s.l.). In the paper a detailed analysis of rocks that host the cave is presented, and also a comprehensive description of the rock morphology and shapes of the cave conduits. Physico-chemical properties of water from cave and from a nearby spring were measured. The temperature and specific electric conductivity determinations indicate a relatively long underground residence time of water which, however, relatively poorly dissolve slowly dissoluble base rock. This could be the explanation for stagnation of the karst deepening with respect to erosional downcutting of the river Chang. In addition, further research is proposed.

Keywords: cave in Devonian carbonates, cave rock morphology, hydrology of karst, physico-chemical analyses, Chang valley, Deqen, Yunnan, China.
\end{abstract}

Izvleček

UDK 911.2:551.435.84(510)

Martin Knez, Janja Kogovšek, Andrej Kranjc, Hong Liu, Metka Petrič \& Tadej Slabe: Jama Shuilian v zgornjem porečju reke Chang (kras severozahodnega Yunnana, Kitajska)

Kras vzdolž zgornjega toka reke Chang (Jangce), v prefekturi Dequen, v severozahodnem delu province Yunnan, je razvit v devonskih karbonatnih kamninah. Jama Shulian, dolga je več kot kilometer, se je oblikovala vzdolž stikov tankoplastovitih metamorfoziranih ter kalcitiziranih peščenih meljevcev in kalcitiziranih meljevcev. Jama ima dva vhoda od katerih je zgornji suh, spodnji pa ima stalen vodni tok. Vhod jame leži v strmem pobočju kakšnih $70 \mathrm{~m}$ nad reko (1965 m n. m.). V članku predstavljamo rezultate podrobne analize kamnine ter izčrpen opis skalnega jamskega reliefa in oblike jamskih rovov. Izmerili smo fizikalno-kemične lastnosti vode, ki izvira iz jame ter vode bližnjega izvira. Temperatura in specifična električna prevodnost vode kažeta na relativno dolgo zadrževanje vode v podzemlju in šibko raztapljanje počasneje topljive spodaj ležeče kamnine. To bi lahko bila razlaga za počasno poglabljanje krasa $\mathrm{v}$ primerjavi $\mathrm{z}$ erozijskim vrezovanjem reke Chang. Predlagamo nadaljnje raziskave.

Ključne besede: jama $\mathrm{v}$ devonskih karbonatnih kamninah, jamski skalni relief, kraška hidrologija, fizikalno-kemične analize, dolina reke Chang, Deqen, Yunnan, Kitajska.

\footnotetext{
${ }^{1}$ Karst Research Institute SRC SASA, Titov trg 2, Si-6230 Postojna, Slovenia, knez@zrc-sazu.si, kogovsek@zrc-sazu.si, kranjc@zrcsazu.si, petric@zrc-sazu.si, slabe@zrc-sazu.si

${ }^{2}$ Institute of Geography, Yunnan University, No. 20 of Xuefu Rd., Kunming 650223, Yunnan, P. R. of China, hongliu@ynu.edu.cn Received/Prejeto: 03.10.2008
} 


\section{INTRODUCTION}

Three of the largest East Asian rivers, Chang Jiang (Yangtze), Lancang Jiang (Mekong), and $\mathrm{Nu}$ Jiang (Salween), take rise relatively close in the eastern part of a Tibetan high plateau, but reach the ocean thousands kilometers apart: Chang Jiang (Yangtze) in the Yellow Sea near Shanghai, Lancang Jiang (Mekong) in South China Sea at Hoshiminh in southern Vietnam, and Nu Jiang (Salween) to Andaman Sea near Yangon (Myanmar). In the east, where the Himalayan arc narrows and turns southeast- and southward, the mentioned rivers cut in deep parallel valleys. At a length of $250 \mathrm{~km}$ they flow almost parallel, distant from one to the other for mere $20-50 \mathrm{~km}$. Then Chang Jiang (Yangtze) turns east in its famous "First Bend «, while the other two rivers continue southeast resp. south. Characteristic for this section of the northwestern most part of the Chinese Yunnan province are parallel mountain chains consisting of peaks above 6,500 m, intermediate plains, and deeply cut (to 3,000 m depth) valleys of the mentioned rivers (Du 2007). Owing to geologic and physiographic reasons, landscape beauty, ecologic characteristics and extraordinary biologic diversity China founded in this territory the Three Parallel Rivers National Park, and in its frame a number of protected areas that were inscribed in 2003 to the UNESCO World Heritage List as Protected Areas of the Three Yunnan Parallel Rivers (Fig. 1). The core of the protected region measures almost $9,400 \mathrm{~km}^{2}$, and the transitory zone additional $7,600 \mathrm{~km}^{2}$. It is situated between $28^{\circ} 12^{\prime}$ and $26^{\circ} 40^{\prime}$ north geographic latitude (UNESCO 2007).
Among the rocks in this territory are also carbonates, and they are karstified. One of the most well known landscape attractions is the narrow and deep gorge through which roars the Chang Jiang (called in this area Jinsha, meaning the Golden Sand), the canyon being called the Tiger Leaping Gorge. A large part of the eastern slopes of the Jinsha river valley, several ten kilometers above the First Bend, consist of limestones. Owing to very steep and uniform slopes the surface karst phenomena are rare, but the karst is manifested by the typical karst hydrology. Above the bottom of the valley, usually 50 - $150 \mathrm{~m}$ high, occur a number of strong karst springs from which the water flows in surface streams into the Jinsha river (Fig. 2).

One among these karst spring is also the original Shuilian spring cave situated near town Zhongdian (county Zhongdian renamed into Xianggelila that is Shangri-La). The river flows here in its bed which is partly cut into solid rock, and partly in alluviums. The alluvial gravel and sand bars are especially extensive in sheltered sites. The foot of slope, several tens of meters above the river, is gently inclined, and there extends the village of Chang Yue. Above it rise very steep the rocky slopes, interrupted at several places with vertical cliffs. About 70 $m$ above the river open the two entrances to the Shuilian cave. From the lower entrance flows the brook that falls a little below as a waterfall several tens meters deep. About ten metres above it is the dry entrance. The splashing waterfall (Fig. 3) gave the cave its name, Shuilian meaning the Water Curtain.

Hydrologic character-
istics of the wider area are

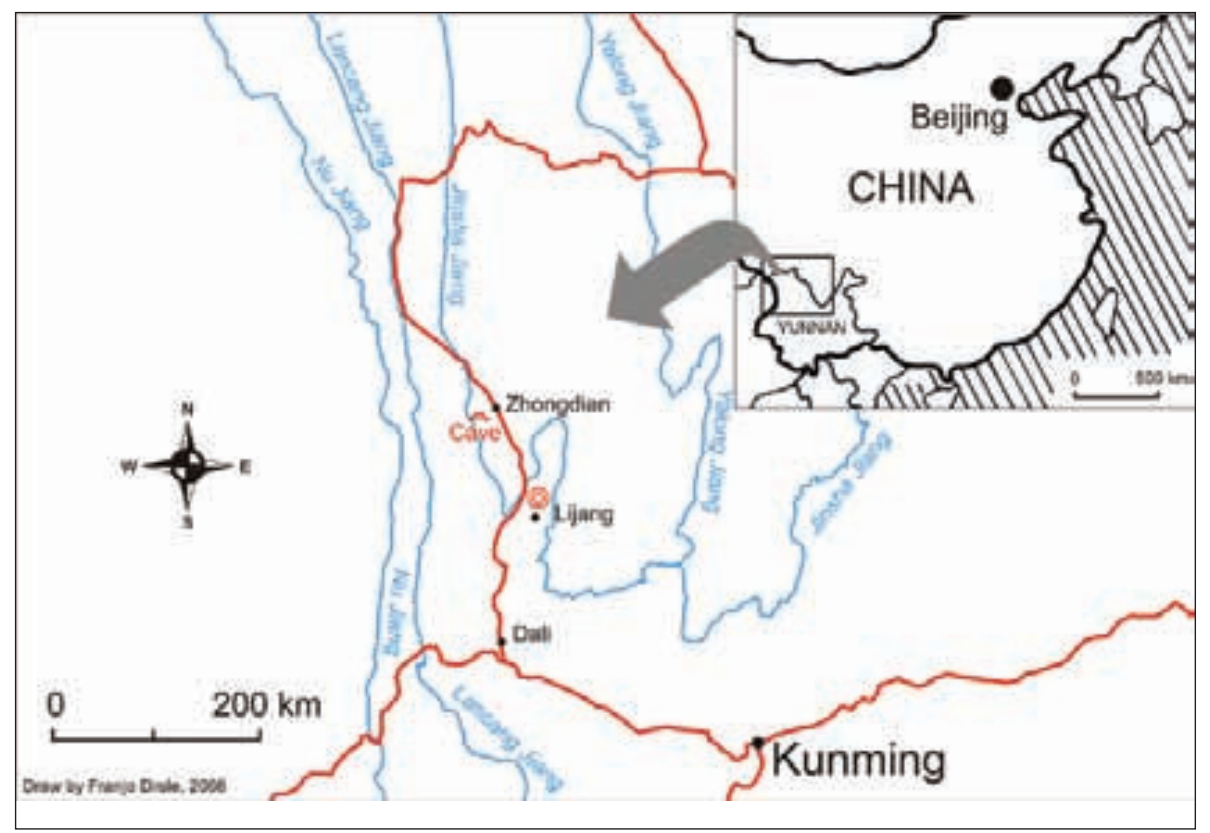

Fig. 1: Location of the studied area. strongly influenced by the position of the Chang Jiang (Yangtze) river and by the geologic contact of rocks of various permeability. The river that plays here the regional erosion basis has cut down its bed deep into the metamorphic rocks. Therefore the contact of metamorphosed sandy siltstones forming the hydrogeologic barrier with the overlying metamorphosed calcitic siltsones extends in this area about 50 to $100 \mathrm{~m}$ above the river. At the contact occur springs discharging water from the carbonate aquifer. 


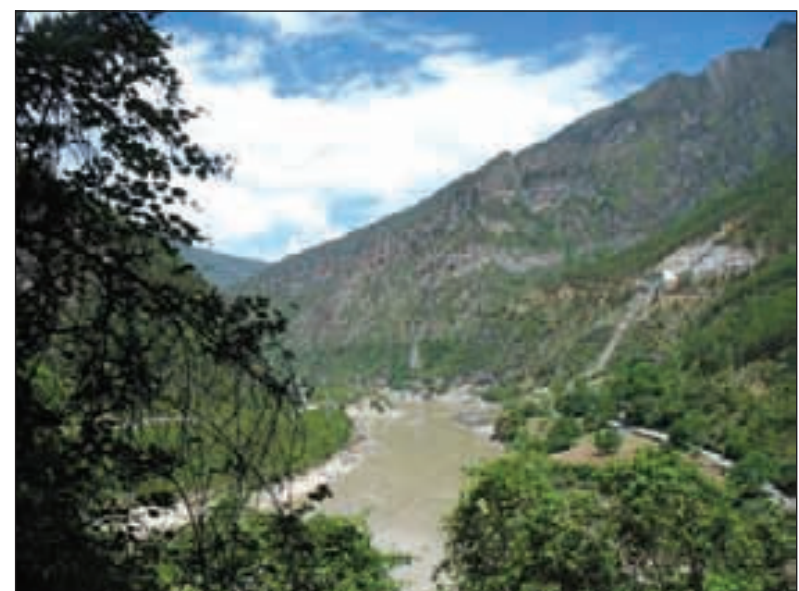

Fig. 2: Jinsha river (Photo: M. Knez).

Some of these springs are used for energy generation owing to their favorable position above the river valley bottom. Water is canalized in pipes to hydroelectric stations that take advantage of the water gradient for electric energy production. The observed spring from the Shulian cave, however, is not used for this purpose. The water is led in the village to a smaller mill wheel.

This part of the Three Parallel Rivers territory underwent a rapid and strong tectonic uplift, and the big high energy rivers deeply cut down their valleys accordingly with the uplift. This is indicated by the morphology of slopes as well as by the karst hydrology. Erosion processes, as deepening of valleys, were faster than the underground karstification. The underground discharge was not able to cope with the surface processes and it lagged behind them. As a result several karst springs, including the one of the Shuilian cave, were left "hanging " about $100 \mathrm{~m}$ above the valley floor. Similar phenomena can be found also in the Slovenian alpine karst, where karst water in a number of springs, as in the case of Savica, Soča and Boka, takes rise high in the slopes above the floors of valleys that were during Pleistocene additionally deepened by glaciers.

Valley slopes of Three Parallel Rivers are presently almost bare, or overgrown with sparse bushes typical for arid regions, and partly by scarce pine tree woods. This is a result of the Man's interference with the natural environment. During the times of highest population pressure on the land all possible surfaces were used for agriculture, and much wood was cut down. This did not affect vegetation only, but had wider and long-term consequences. One of them was also the radical increase of the soil erosion which is recorded in the sediments. They can be observed at many places in cuts of small valleys and ravines that descend from slopes towards the river. On the fluvial sediments (sand and gravel) the soil deposits might be up to several meters thick. The

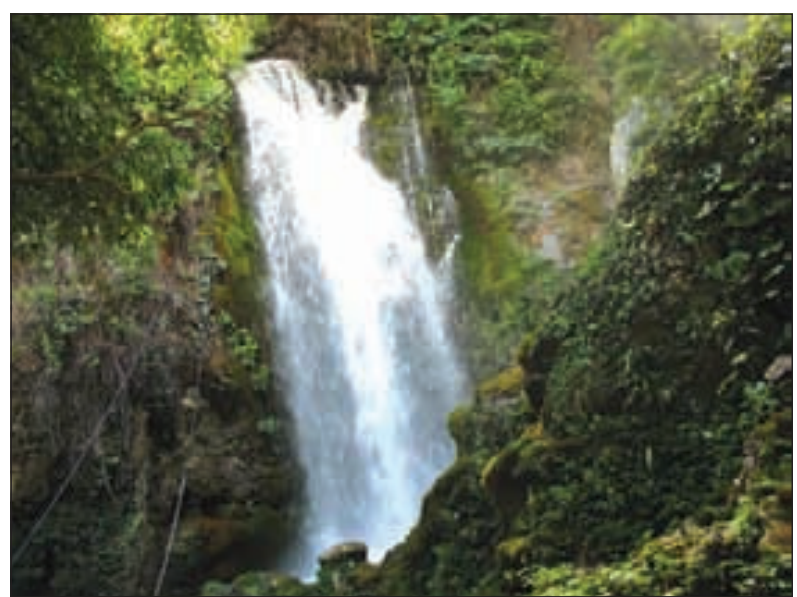

Fig. 3: Water falling from the cave making "water curtain" Shuilian (Photo: T. Slabe).

profiles clearly show that soil did not form in situ, but was deposited there by other processes, perhaps as colluvial soil (Fig. 4).

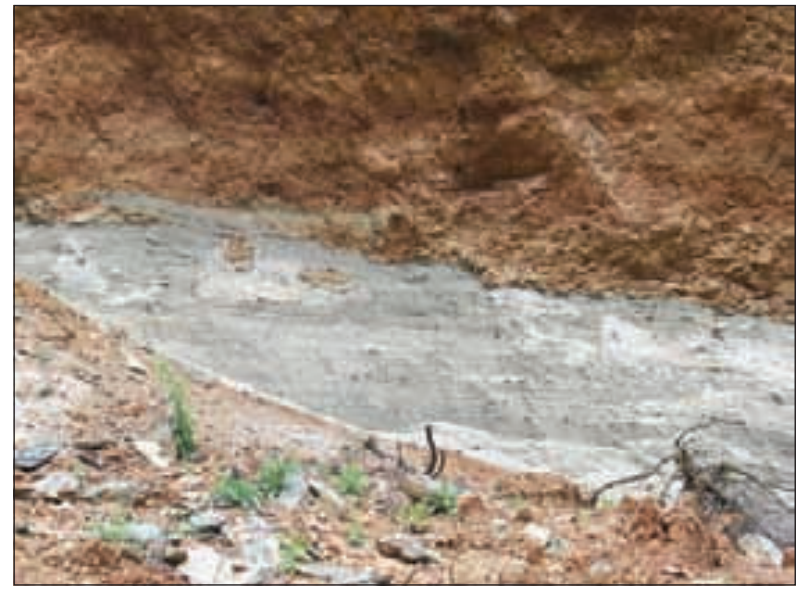

Fig. 4: Quick change from deposition to erosion illustrated by sediments: fluvial sand (gray) covered by thick soil (reddish brown) (Photo: A. Kranjc).

As the climate is relatively dry, the forest does not renew readily. At present the societal and economic circumstances changed. In many places the abandoned culture terraces can be seen, and the trees and woods are getting more abundant. Reforestation is everywhere in course. Owing to hard accessibility reforestation is carried out mainly by planes that sow pine-tree seeds from the air.

The Shuilian cave, the entrance of which is situated $70 \mathrm{~m}$ above the average water level of the Chang Jiang (Yangtze) River, is $1,190 \mathrm{~m}$ long (Fig. 5). In the entrance part it consists of two passages that after the first third of cave joined into a unique water passage. The upper passage is old and dry, and through the 


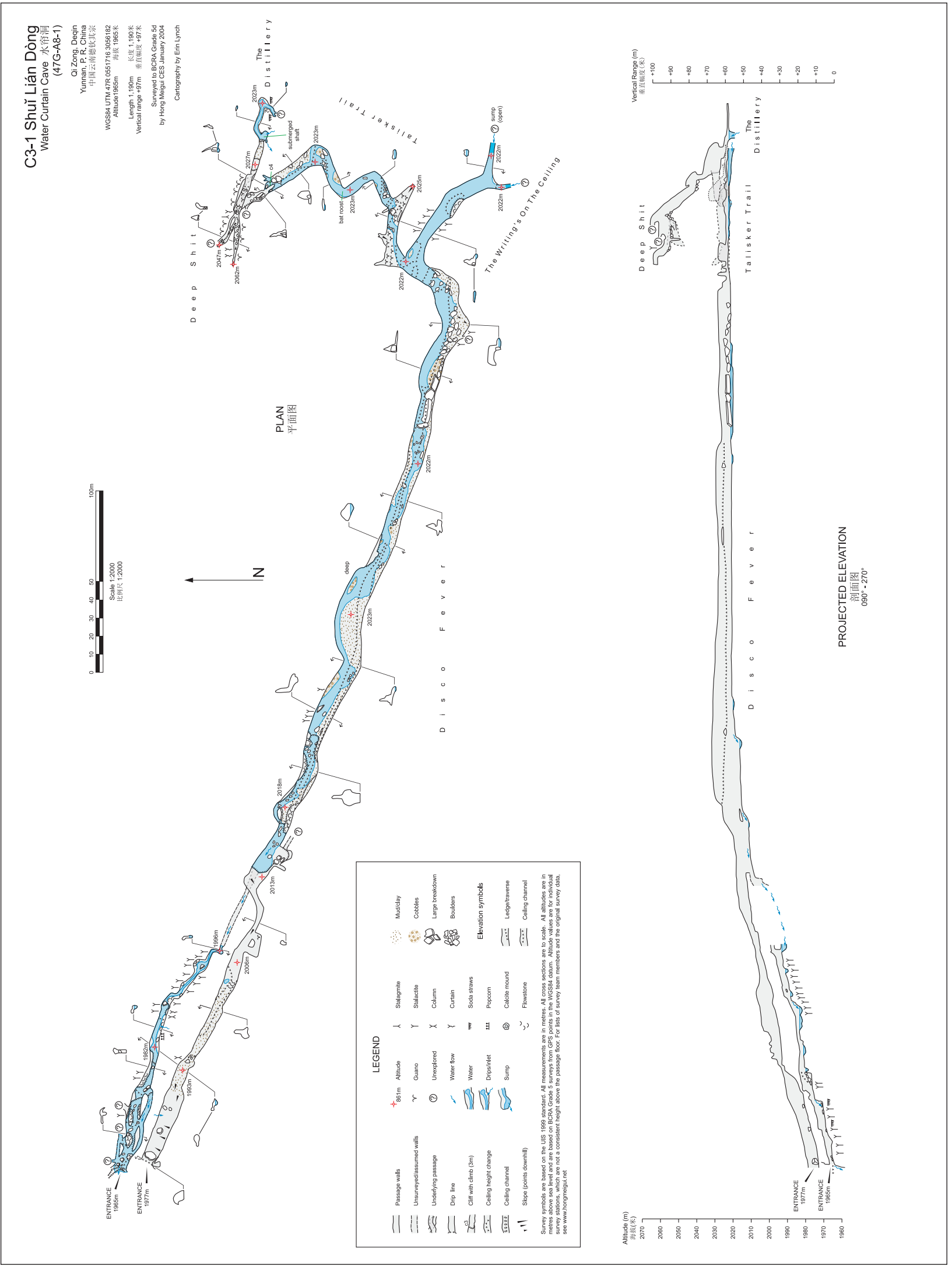

Fig. 5: Survey of Shuilian cave by Erin Lynch. 
lower passage flows the water stream that discharges in the waterfall.

Position, shape, geologic, speleomorphologic and hydrogeologic investigations shed light on the way of the cave formation and the most important stages of its evo- lution, but also on the characteristics of the karst aquifer, the waters that flow along the contact with less permeable rocks, and the development of the rapidly incising canyon of the Chang Jiang (Yangtze) River.

\section{GEOLOGIC STRUCTURE}

In the narrow surroundings of the cave the Lower and Middle Devonian rocks are exposed. The belt of Devonian beds extends southeast-northwest, and is separated from beds in northeast and in southeast by two deep faults. In the northeast Devonian rocks are in contact with the Upper Carboniferous limestones and shales, and in southwest with the Middle to Upper Silurian limestones and dolomites. All mentioned beds are strongly folded or tilted to almost vertical positions. Along both faults that delimit the Devonian beds compression occurred in geologic history which led to forming of a folded structure in which the beds dip on an average $80^{\circ}$ in northeast, and between 30 and $60^{\circ}$ in southwest.

The cave formed at contact (Fig. 6) between the Lower and Middle Devonian rocks. The lower Devonian rocks are calcitized and metamorphosed sandy siltstones, and the Middle Devonian ones high grade metamorphic calcitic siltstones of high carbonate content (Tab. 1).

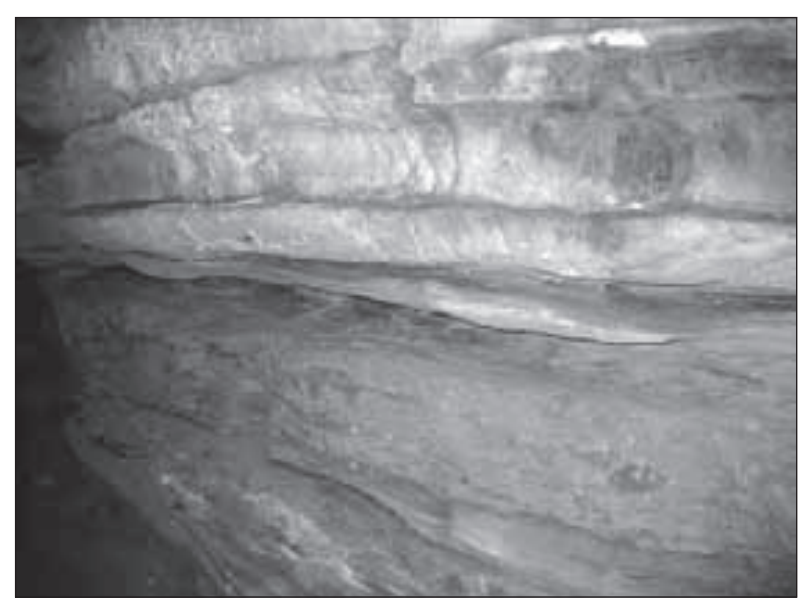

Fig. 6: Contact of calcitized and metamorphosed sandy siltstones and highly metamorphosed calcitic siltstone (Photo: M. Knez).

Calcitized and metamorphosed sandy siltstones are finely bedded and of red brown color owing to the presence of iron oxides. Alizarine coloring is intense, calcite contents exceed $60 \%$ (Tab. 1, sample 1). The preponderance of sparitic calcite is observable also macroscopically. Aggregates of polycrystalline quartz attain $0.5 \mathrm{~mm}$.
Quartz contents are estimated at 5-7\%. Iron oxides impregnate the rock, and in addition they occur in irregular aggregates and on original schistosity planes with muscovite and sericite particles. The rock is cut by calcite veins of several generations.

Calcitized and metamorphosed sandy siltstones a few decimetres thick that lie just below the metamorphosed limestones are finely laminated, the laminas being up to $2 \mathrm{~mm}$ thick. The cross-bedding pinches out lentiformly at the contact with Middle Devonian beds. In areas where calcitization has not been entirely completed, the rock is of alternating reddish brown and dark grey colors. Reddish brown lenses contain iron oxide minerals, most probably limonite. Coloration with alizarine red is very intense, the indicated calcite contents being high, between $80 \%$ and $90 \%$ of the total rock (Tab. 1, samples 2, 3). The rock consists of sparitic calcite (at least 70\%). In very low amounts polycrystalline quartz (to $5 \%$ ) is present, and in traces sericitemuscovite (up to $2 \%$ ), the rest being represented by iron oxides, chiefly limonite. The latter occurs as impregnations, and is concentrated on schistosity planes that apparently coincide with the bedding planes.

The original rock of the calcitized and metamorphosed sandy siltstone was most probably silty sandstone or sandy siltstone. The rock was metamorphosed, and most probably during speleogenesis strongly calcitized.

The highly metamorphosed calcitic siltstones of high carbonate contents (Tab. 1, samples from 4 to 9) higher in the cave profile are bedded with the beds up to several $10 \mathrm{~cm}$ thick. The rock is strongly altered. The original rock was sedimentary, most probably calcitic siltstone and fine grained sandstone that were later metamorphosed to a marble-like rock (Fig. 7). During this process the iron oxides separated from phyllosilicates owing to substitution by calcite.

A smaller part of the lower extent of the passage was formed by erosional processes in less permeable beds of calcitized and metamorphosed sandy siltstones of red color. The reason for high calcite contents in these beds are also abundant fissures filled with sparitic calcite. 


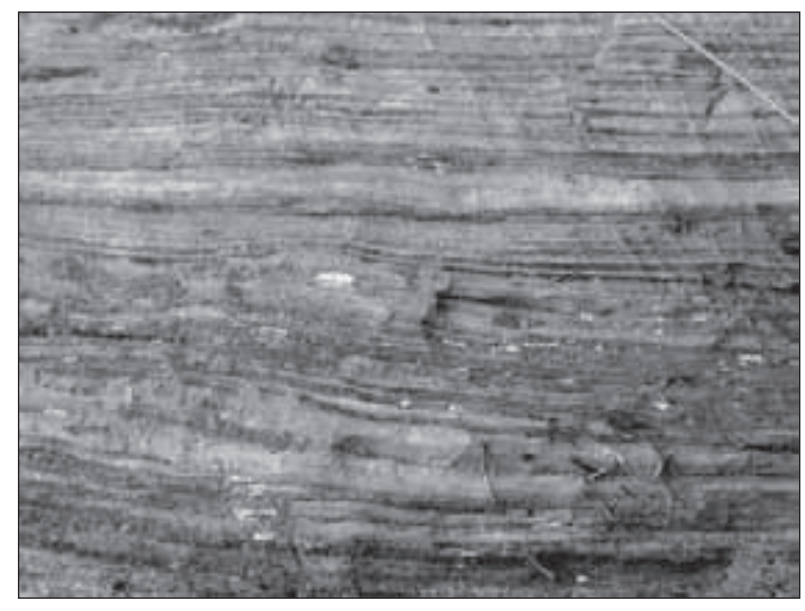

Fig. 7: Fine grained sandstone that were later metamorphosed to a marble-like rock (Photo: M. Knez).

On dissected sides of the passage variable resistance of individual carbonate beds in the vertical direction is observable.

\begin{tabular}{|c|c|c|c|c|c|c|c|}
\hline Sample & CaO (\%) & MgO (\%) & calcite (\%) & $\begin{array}{c}\text { dolomite } \\
(\%)\end{array}$ & $\begin{array}{c}\text { total } \\
\text { carbonate } \\
(\%)\end{array}$ & $\begin{array}{c}\text { CaO/Mg0 } \\
(\%)\end{array}$ & $\begin{array}{c}\text { insoluble } \\
\text { residue } \\
(\%)\end{array}$ \\
\hline $\mathbf{1}$ & 33.64 & 1.93 & 56.34 & 7.74 & 64.08 & 17.43 & 35.92 \\
\hline $\mathbf{2}$ & 41.18 & 3.2 & 65.99 & 13.83 & 79.82 & 13.64 & 20.18 \\
\hline $\mathbf{3}$ & 50.47 & 0.81 & 87.09 & 3.68 & 91.77 & 62.31 & 8.23 \\
\hline $\mathbf{4}$ & 55.29 & 0.56 & 97.27 & 2.58 & 99.85 & 98.73 & 0.15 \\
\hline $\mathbf{5}$ & 55.21 & 0.62 & 96.97 & 2.85 & 99.82 & 89.00 & 0.18 \\
\hline $\mathbf{6}$ & 55.18 & 0.64 & 96.87 & 2.95 & 99.82 & 86.22 & 0.18 \\
\hline $\mathbf{7}$ & 55.09 & 0.58 & 96.77 & 2.67 & 99.53 & 98.37 & 0.47 \\
\hline $\mathbf{8}$ & 55.12 & 0.56 & 96.97 & 2.58 & 99.55 & 98.42 & 0.45 \\
\hline $\mathbf{9}$ & 55.18 & 0.64 & 96.86 & 2.95 & 99.81 & 86.06 & 0.19 \\
\hline
\end{tabular}

Tab. 1: Calcimetric data of rock samples. Samples from 1 to 3 are calcitized and metamorphosed sandy siltstones of lower Devonian age, rock samples 4 to 9 are Middle Devonian metamorphosed calcitic siltstones.

Rocks in this area became densely fissured as a result of intense tectonic activity. Later fissures, mostly up to $1 \mathrm{~mm}$ wide, became filled with calcite cement. A somewhat stronger fault, along which the shift can be seen, occurred in the central part of the passage.

\section{ROCK RELIEF OF CAVE AND SHAPE OF PASSAGES}

The cave rock relief and longitudinal and transversal sections of the passages give insight into the way of water flow through the cave, the mechanism of shaping the cave and the most important stages of its development.

The rock relief can be divided into two groups of rock features. The first group assembles the rock features that indicate slower water flow through the cave when it was inundated, and the second group features that indicate faster water flow velocities. The second ones comprise traces of the present water flow in the lower part of the water passage, and in conduits of smaller cross section, before the discharge, along the entire periphery. The cave originated and has been shaped at the contact of underlying calcitized and metamorphosed sandy siltstones and intensely metamorphosed calcitic siltstones of which consists the periphery of the passage's upper parts. The prevailing process in the lower parts is consequently mechanical erosion, and in their upper parts dissolution of rocks. With the first process the cave is evolving also today.

Traces of the water flow through the formerly flooded cave are large scallops and ceiling pockets (Fig. 8) as well as wall pockets. They were shaped by the slower water flow. They arose in the beds of metamorphosed calcitic siltstones. Large scallops (Slabe 1995) of diameters of up to $0.7 \mathrm{~m}$, are the best preserved on passage walls. The deepest ones, to $15 \mathrm{~cm}$, occur at bedding planes. The most characteristic features are the pockets. They can be simple or composed. Some of them are several (up to 3 ) m high. The deepest ones that formed at fissures tend to narrow upwards. They consist of several floors, or their tops may be composed of several pockets. They are elongated along fissures, composed, they may be stringed one next to the other. In places they are fastened together into ceiling cupolas. On parts of ceiling that were shaped along a well expressed vertical fissure, a ceiling channel (Fig. 9) can form, the top of which developed into pockets. The ceiling channel is in places several meters high, while in other places it completely pinches out. On such places, on walls of ceiling channels and on walls of cupolas occur vertical and semi-circular notches that may be several meters long. At bedding planes and at the widest open parts of contacts of different rocks wall pockets formed that are several meters deep. Their upper part is of dome-like shape, but the lower part is more or less horizontal. Such shape is governed by the lower, less carbonate containing rock or sediments that deposited in the lower part of the wall pocket, and that preserved it from faster rock dissolution. Quite often several smaller pockets are connected into a wall cupola, 


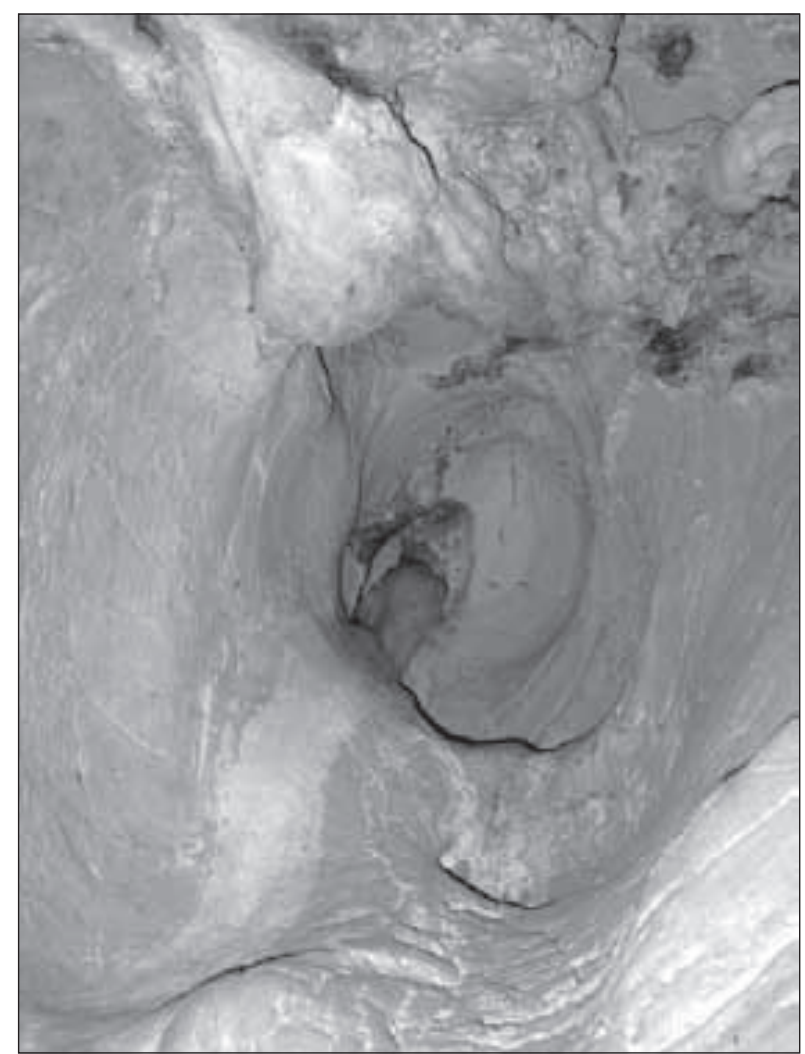

Fig. 8: Ceiling pocket (Photo: T. Slabe).

and they rise, like connected into a vertical channel, one above the other.

Characteristic rock features are also the wall notches (Slabe 1995). They formed at contact of two different rocks and at bedding planes. Some of them are asymmetrical and semicircular. Their upper semicircular part is in metamorphosed calcitic siltstones and the flat bottom on the underlying less permeable rock (Fig. 6). In other places are wall notches better developed in the lower, less carbonate rock, while the metamorphosed calcitic siltstone stands out as a projecting step in the wall. Elsewhere there are no morphologic features at the boundary between two rocks. The wall notches are often ribbed with scallops and dissected by wall pockets.

Most of the upper part of the passage circumference has been shaped by water that has been lastingly condensing in the upper parts of passage. On ceiling and walls remains of sinter are found, an indication of the changed microclimatic conditions in the passage. The cave obviously became wider opened to exterior influences. The surface of rock and of sinter is finely dissected. At the better soluble parts of rock, mainly cut by fine cracks that pass through rock in various directions, small etchings formed that reach up to $1.5 \mathrm{~cm}$ in depth.

The lower parts of passage that are frequented by the water flow were shaped predominantly by mechanic ac-

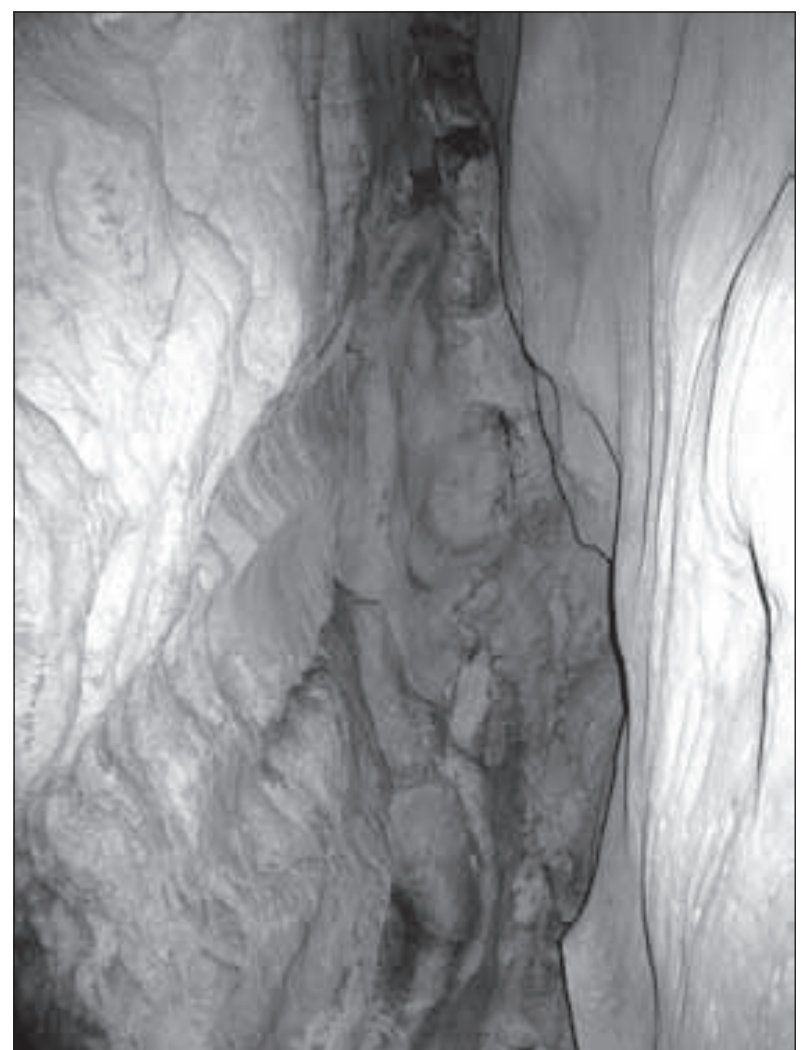

Fig. 9: Ceiling channel (Photo: T. Slabe).

tion of the water load that included also sand and smaller pebbles. Formed were potholes, scallop-like shapes and wall notches, wall pockets and floor channels. Longitudinal wall notches with a diameter of decimeter size are developed along bedding planes. Some of them deepen the small wall pockets. Their diameters may attain half a meter. They are the result of mechanical action of water flow that tears off the rock particles, and chisels the rock with the transported material it drives into whirling. Along the entire water passage, and also on floor of dry parts of cave the floor channels can be traced. They represent the trace of cutting of the water flow into the rocky floor over the entire surface, and in broader parts of cave also of periodic smaller water streams that flowed only over the lowest parts of the channel. The surface of the channel has been mechanically smoothened and rounded, especially somewhat higher, from $1 \mathrm{~m}$ to 1 . $5 \mathrm{~m}$ above floor, in the reach of higher waters. Into the floor of channel are chiseled potholes that measure up to $3 / 4$ metre in diameter. The smaller ones measure only a few centimeters, however. In the prevailingly calcitized and metamorphosed sandy siltstones the water flow that whirls along the rough surface of the rock consisting of grains, excavates also scallop-like elongated, up to $3 \mathrm{~cm}$ long hollows. Also these features are mostly the consequence of mainly mechanical excavation of the rock by 


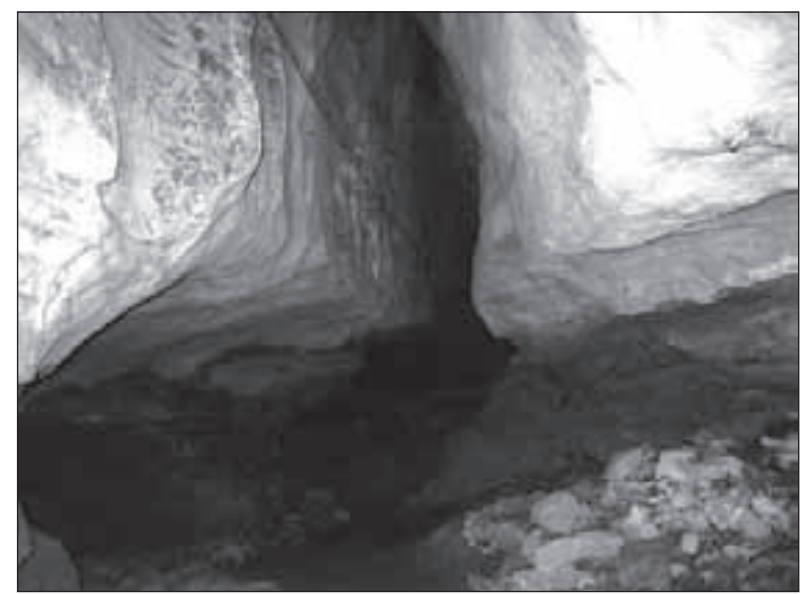

Fig. 10: Cross-like shape of cave passage (Photo: T. Slabe).

the mass of the water current which also carries insoluble particles. In the entrance part of cave the walls and sinter are covered by mosses and liverworts that finely dissect their surface.

From the transversal sections of passages various ways of formation of the cave at contact of two rocks can be deduced. Water that filled the empty space in the flooded zone first percolated along the contact cut by vertical cracks. At the crack a vug formed that first spread along contact of beds of different rocks, and then spread upwards into the fissured upper part in the metamorphosed calcitic siltstone. In the flooded zone consequently a cross-like shape formed with a larger, higher upper part (Fig. 10). After lowering of the water level the water current kept eroding only into the calcitized and metamorphosed sandy silstone, and it deepened and widened the lower part of passage. Certain smaller passages preserved the prevailingly round cross-sec-

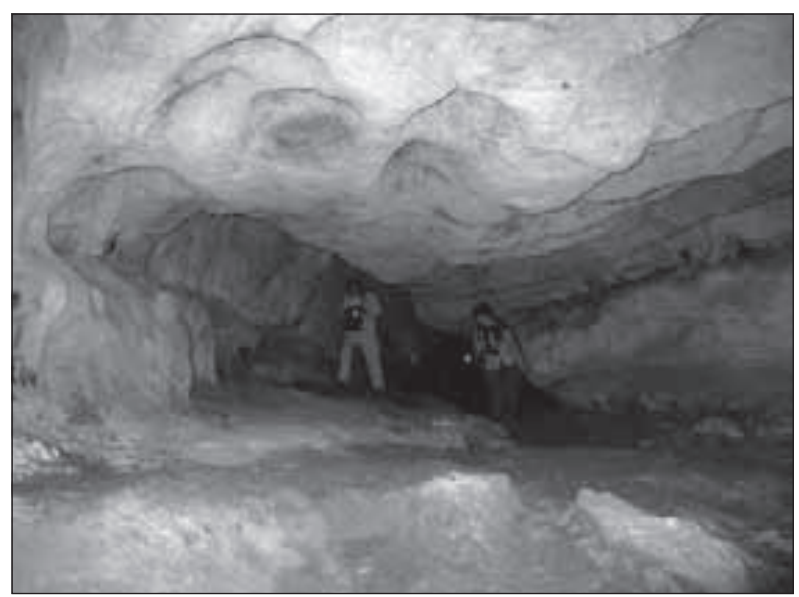

Fig. 11: Cross section of the passage with larger upper part developed in rock of higher carbonate content (Photo: T. Slabe).

tion. Their larger part formed in the metamorphosed calcitic siltstone. In the lower, metamorphosed sandy siltstone, however, they formed below a semicircular floor channel (Fig. 11). Such passages did not form at distinct fissures. The cross-section of larger passages, on the other side, indicates that they originated from joining of several smaller circuits. Their ceiling consists of several arches. The contact of described rocks was not of uniform permeability, however. The higher water permeability at vertical fissures was mentioned already. The parts of highest permeability assumed the part of water conduit, while the impermeable parts of the contact remained preserved. In more spacious parts of the passages pillars can be seen that are as a rule the narrowest at the contact, they are often indented by circular wall notches, while upwards they widen into the vault of the cave ceiling.

\section{HYDROGEOLOGICAL CHARACTERISTICS}

At day of our visit the water flowed from the Shuilian cave through the lower passage at $1,965 \mathrm{~m}$ a.s.l., while in the interior we reached the water through the upper dry passage after approximately $150 \mathrm{~m}$. The discharge was not measured, but was estimated at about 100 to $200 \mathrm{l} / \mathrm{s}$.

Measured were the basic physical parameters of water, and collected was a sample for chemical analysis. Also in the cave that has developed at contact of two lithologically differing rocks, the water current was cut into the underlying metamorphosed sandy siltstones. There were no appreciable discharges of percolating water through ceiling consisting of carbonate rocks at the day of our visit. An exception was a smaller trickle of water in which the specific electric conductivity was measured.

The river has several surface affluents. Two of them encircle the recharge area of the Shuilian spring. In the field we visited the left affluent that flows into the river about $1.5 \mathrm{~km}$ northwards. Also in this ravine that is equally cut into the metamorphosed sandy siltstones several springs were observed in the slope above the river bed. The highest contribution to the flow of the surface stream comes from the larger spring near Shuilian (Tab. 2), situated higher up in ravine just above the river bed at the contact with metamorphosed calcitic siltstones (Fig. 12). At the spring the basic physical characteristics 
of water were measured (Tab. 2) and a sample for chemical analysis collected. The discharge of the spring was estimated to 200-300 1/s. The described situation was recorded in time of low to medium waters at the beginning of the rainy period. In view of climatic conditions higher flows can be expected after the rainy season peak toward the end of summer.

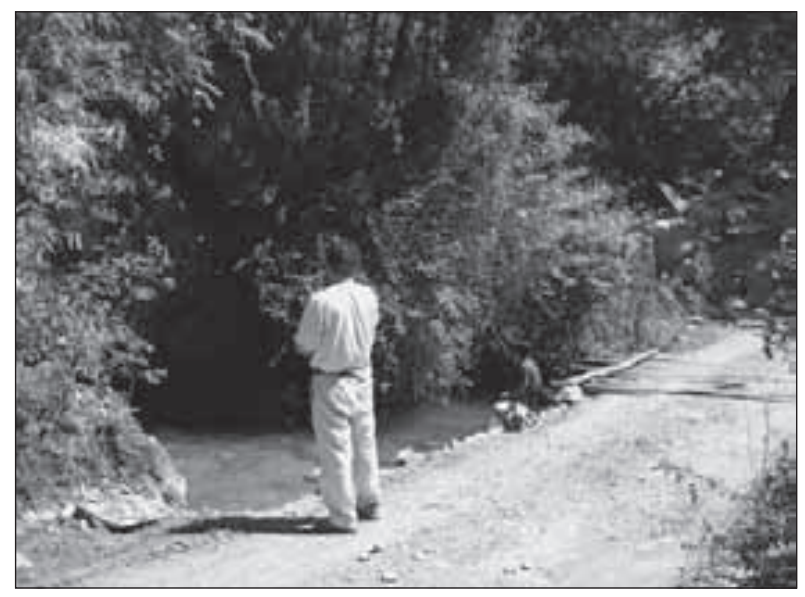

Fig. 12: Spring near Shuilian recharges the left affluent of the Jinsha river (Photo: J. Kogovšek).

Above the river and the spring, the slope rises steeply, and it reaches about $10 \mathrm{~km}$ eastward the high plateau with altitudes above $4,000 \mathrm{~m}$ a. s. 1 . There are exposed rocks of very low permeability on which precipitation water collects in small lakes and surface streams. At contact with carbonate rocks of higher permeability it sinks underground. It is possible it flows also to the observed springs, but to verify this connection additional investigations would be needed.

\section{RESULTS OF WATER ANALYSES}

The groundwater in the Shuilian cave sampled at the spring near entrance displayed on 28 May 2007 the temperature of $9.2^{\circ} \mathrm{C}$ and specific electric conductivity (SEC) of $154.4 \mu \mathrm{S} / \mathrm{cm}$. The low SEC value was confirmed also by chemical analyses. Water contained only $1.73 \mathrm{meq} / 1$

Tab. 2: Physico-chemical characteristics of the sampled waters: T-temperature, SEC-specific electric conductivity, $\mathrm{Ca}+\mathrm{Mg}$-total hardness, $\mathrm{Ca}$-calcium, $\mathrm{Ca} / \mathrm{Mg}$-ratio calcium/magnesium, $\mathrm{Cl}$-chlorides (28 May 2007).

\begin{tabular}{|c|c|c|c|c|c|c|c|}
\hline \multirow[t]{2}{*}{ Place } & \multirow{2}{*}{$\begin{array}{l}\mathrm{T} \\
{ }^{\circ} \mathrm{C}\end{array}$} & \multirow{2}{*}{$\begin{array}{c}\text { SEC } \\
\mu \mathrm{S} / \mathrm{cm}\end{array}$} & Carbonates & $\mathrm{Ca}+\mathrm{Mg}$ & $\mathrm{Ca}$ & $\mathrm{Ca} / \mathrm{Mg}$ & \multirow{2}{*}{$\begin{array}{c}\mathrm{Cl}^{-} \\
\mathrm{mg} /\end{array}$} \\
\hline & & & \multicolumn{4}{|c|}{ meq/l } & \\
\hline Water flow in Shuilian & 9.2 & 154 & 1.73 & 1.72 & 1.48 & 6.4 & 2 \\
\hline Spring near Shuilian & 9.3 & 165 & 2.01 & 1.88 & 1.52 & 4.2 & 1 \\
\hline Percolating water & & 355 & & & & & \\
\hline
\end{tabular}

carbonates $\left(106 \mathrm{mg} \mathrm{HCO}_{3}^{-} / \mathrm{l}\right)$, and a total hardness of $1.72 \mathrm{meq} / \mathrm{l}\left(86 \mathrm{mg} \mathrm{CaCO}_{3} / \mathrm{l}\right)$. Calcium concentration was $1.48 \mathrm{meq} / \mathrm{l}\left(30 \mathrm{mg} \mathrm{Ca}{ }^{2+} / \mathrm{l}\right)$, and followingly the ratio $\mathrm{Ca} /$ $\mathrm{Mg}=6.4$. Water contained only $2 \mathrm{mg} \mathrm{Cl}^{-/ 1}$ and low sulfates concentration, only a few $\mathrm{mg} / \mathrm{l}$ (Tab. 2).

The relatively low water temperature indicates a longer residence in the wide and high hinterland, and low SEC and hardnesses the absence of flow through the easily soluble carbonate rocks which would lead to dissolution of carbonate minerals and higher values of their constituents in water.

A possible source of water is the surface stream from the area of very low permeable rocks on the high plateau about 2,000 $\mathrm{m}$ higher. With respect to chemical characteristics of water in the cave we presume a rapid flow through the metamorphosed calcitic siltstones respectively continuous flow along their contact with the metamorphosed sandy siltstones, not much different from the flow in the Shuilian cave. In percolating water (Tab. 2) that is fed into cave through ceiling, a considerably higher value of SEC $(355 \mu \mathrm{S} / \mathrm{cm})$ was measured, which reflects its percolation through a higher carbonate containing rock and a more abundant dissolution of carbonates. Since the samples were collected at the beginning of the rainy season and considering our knowledge of water flow through the vadose zone in the Slovenian karst (Kogovšek 2007; Kogovšek \& Petrič 2006) we presume that the first rainfalls at the beginning of the rainy period were used mainly for filling up the vadose zone of the karst part of the catchment that was drained during the previous draught period. For this reason the discharge from it was low at the time of our sampling, which resulted also in the chemical composition of the spring water. Probably a larger contribution of water from the vadose zone with a higher carbonates' concentration can be expected in the rainy season. Of course this could be established only with appropriate additional measurements and analyses.

Also the larger spring, the Spring near Shuilian (Tab. 2) that feeds the left affluent of river $1.5 \mathrm{~km}$ northward, displays physico-chemical characteristics very similar to those of the spring from the Shuilian cave, as evident from Tab. 2.

The close chemical correspondence of the two examined springs indicates very similar recharge areas (possibly some parts are common to both), and a very similar underground flow. 


\section{CONCLUSION}

The Shuilian cave originated at the contact between the underlying little permeable Lower Devonian calcitized and metamorphosed sandy siltstones and the overlying higher permeable Middle Devonian metamorphosed calcite siltstones.

Formation of the cave at contact of rocks differing much with respect to erosion and corrosion led to the rise of typical cross sections. The rock relief with preserved traces of slow water flow in the flooded zone bears evidence of the rapid change of hydrologic condi- tions from phreatic to epiphreatic and to vadose ones. This change has been the consequence of the rapid deepening of the river valley. In the less permeable rocks the hanging water flow is preserved. Hydrogeologic position of springs and physico-chemical characteristics of water permit the conclusion that the Shuilian cave and neighboring springs are recharged by water from the vadose zone in the metamorphosed calcitic siltstones and by water from the high plateau approximately $2,000 \mathrm{~m}$ above the river.

\section{ACKNOWLEDGMENTS}

The results follow from several years of the project cooperation between the Yunnan Institute of Geographv, Yunnan university, Kunming, China, and the Karst Research Institute SRC SASA, Postojna, Slovenia. Presently there is cooperation in the project Influence of airport construction to the karst aquifer and water quality in it - A study of the Qinglongdong spring catchment, Kunming, China (BI-CN/07-09-015), financed by Slovene Research Agency. We sincerely thank also Dr. Polona Kralj from the Geologic Survey of Slovenia for examining of rock samples.

\section{REFERENCES}

Du X. (Ed.), 2007: Atlas of China.- Sinomaps Press, Beijing.

Kogovšek, J., 2007: Rainwater percolation dynamics assessment through the vadose karst zone on the basis of discharge measurements.- Acta carsologica, 36, 2, 245-254, Ljubljana.

Kogovšek, J. \& M. Petrič, 2006: Tracer test on the Mala gora landfill near Ribnica in south-eastern Slovenia.- Acta carsologica, 35, 2, 91-101, Ljubljana.
Slabe, T., 1995: Cave Rocky Relief and its Speleogenetical Significance.- Zbirka ZRC 10, Ljubljana.

UNESCO, 2007: Sites.- [Online]. Available from: http:// whc.unesco.org/sites/1083-loc.htm/ [Accessed 21 $1^{\text {st }}$ August 2007]. 